\title{
Analisis Kesulitan Dan Self-Efficacy Siswa Ma Dalam Pemecahan Masalah Matematika
}

\author{
Samsul Hadi \\ Program Studi Pendidikan Guru Sekolah Dasar, Institut Pendidikan Nusantara Global \\ Indonesia, 83511 \\ samsulhadi@nusantaraglobal.ac.id
}

\begin{abstract}
Abstrak. Pemecahan masalah merupakan bagian proses terpenting dalam pembelajaran matematika yang membutuhkan self-efficacy siswa dalam penyelesaian masalah matematika. Penelitian ini bertujuan untuk menganalisis kesulitan-kesulitan dan self-efficacy siswa MA memecahkan masalah matematika. Penelitian ini menggunakan pendekatan kualitatif berbasis studi kasus. Subjek penelitian terdiri dari 22 siswa kelas 11 di salah satu MA Negeri di Lombok, NTB. Sampel penelitian ditentukan dengan purposive sampling. Instrumen yang digunakan berupa tes diagnostik terdiri atas 6 soal uraian, angket self-efficacy, dan pedoman wawancara. Hasil penelitian menunjukkan bahwa kesulitan siswa dalam pemecahan masalah matematika terletak pada pengetahuan faktual, konseptual, prosedural, dan metakognitif. Jenis kesulitan yang dialami siswa yaitu siswa kesulitan mengingat fakta, kesulitan mengingat konsep, memahami fakta dan konsep, menerapkan konsep, menerapkan prosedur penyelesaian masalah, menganalisis prosedur, mengevaluasi faktual, mengevaluasi konsep, mengevaluasi prosedur, dan mengomunikasikan metakognitif. Faktor-faktor kesulitan yang dialami siswa MA dalam memecahkan masalah matematika yaitu siswa merasa waktu pengerjaan soal tidak cukup, siswa belum terbiasa menyelesaikan soal-soal non rutin dalam pembelajaran matematika, siswa kesulitan dalam bahasa, konsep, terapan, dan penggunaan stategi yang tepat dalam pemecahan masalah matematika sehingga siswa mudah menyerah, dan siswa tidak mampu mengaitkan konsep yang satu dengan yang lain dalam penyelesaian masalah matematika yang dikerjakan. level Self-efficacy siswa MA berada pada kategori tinggi dalam menyelesaikan masalah matematika.
\end{abstract}

Kata Kunci: Masalah Matematika, Kesulitan dalam Pemecahan Masalah, Pemecahan Masalah Matematika, Self-Efficacy.

Abstract. Problem solving is the most important part of the process of learning mathematics which requires students' self-efficacy in solving mathematical problems. This study aims to analyze the difficulties and self-efficacy of MA students in solving mathematical problems. This research uses a qualitative approach based on case studies. The research subjects consisted of 2211 th grade students in one of the State MA in Lombok, NTB. The research sample was determined by purposive sampling. The instrument used in the form of a diagnostic test consists of 6 problem descriptions, self-efficacy questionnaires, and interview guidelines. The results showed that students' difficulties in solving mathematical problems lay in factual, conceptual, procedural, and metacognitive knowledge. Types of difficulties experienced by students are students having difficulty remembering facts, difficulty remembering concepts, understanding facts and concepts, applying concepts, applying problem solving procedures, analyzing procedures, evaluating factual, evaluating concepts, evaluating procedures, and communicating metacognitive. Difficulty factors experienced by MA students in solving mathematical problems are students feel the time working on problems is not enough, students are not accustomed to solving non-routine problems in learning mathematics, students have difficulty in language, concepts, applied, and the use of appropriate strategies in solving mathematical problems so that students give up easily, and students are not able to associate concepts with one another in solving mathematical problems being worked on. Selfefficacy level MA students are in the high category in solving math problems.

Keywords: Mathematical Problems, Difficulties in Problem Solving, Mathematical Problem Solving, Self-Efficacy. 


\section{PENDAHULUAN}

Masalah klasik yang dihadapi siswa dalam pembelajaran matematika adalah rendahnya kemampuan siswa dalam menyelesaikan soal-soal non rutin. Hal ini mengakibatkan secara umum prestasi siswa di pendidikan dasar dan menengah bisa dikatakan rendah. Selain itu, dari hasil survei PISA 2018, prestasi siswa Indonesia masih berada pada level bawah dibandingkan negara-negara lainnya seperti Thailand, Brunei Darussalam, dan Malaysia. Misalnya, nilai skor membaca, matematika, dan sains berturut-turut pada skor 371, 379, dan 396. Nilai ini mengalami penurunan dibandindkan pada tahun 2015 (OECD, 2018). Pada dasarnya pembelajaran matematika memiliki peran yang sangat penting karena matematika merupakan disiplin ilmu dasar yang digunakan secara luas dalam kehidupan. Chambers (2008) mengatakan bahwa matematika merupakan pengetahuan mengenai pola-pola abstrak yang memiliki karakteristik sebagai alat dalam memecahkan masalah, sebagai pondasi kajian ilmiah dan teknologi, serta dapat memberikan cara-cara memodelkan situasi dalam kehidupan nyata. Dalam pembelajaran matematika diharapkan siswa dapat meningkatkan kemampuan berpikir efektif, kritis, logis, sistematis, kreatif, cermat, dan efisien dalam memecahkan masalah.

NCTM (2000) bahwa pada dasarnya pemecahan masalah dalam pembelajaran matematika meupkan suatu bagian kompetensi siswa yang harus dimiliki dalam pembelajaran matematika dalam mengembangkan pengetahuan matematika di setiap masalah yang dihadapi siswa. Hal ini sejalan dengan Bell (1978) bahwa pemecahan masalah matematika dapat membantu siswa dalam mengembangkan kemampuan matematika mereka dan mengaplikasikan kemampuan tersebut pada berbagai situasi. Namun, faktanya bahwa masih banyak siswa mengalami kesulitan dalam pemecahan masalah matematika. Belum optimalnya kemampuan pemecahan masalah matematika siswa tidak hanya disebabkan oleh sifat matematika yang abstrak tersebut melainkan juga juga tidak terlepas dari proses pembelajaran matematika yang masih berpusat pada guru yaitu guru hanya menerangkan materi, memberi contoh soal dan memberikan latihan soal tanpa siswa diberikan kesempatan berpkir dan mengembangkan kreatifitas siswa dalam menyelesaikan masalah yang dihadapi (Amri \& Abadi, 2013). Selain itu, Rendahnya kemampuan siswa dalam pemecahan masalah matematika siswa dipengaruhi oleh faktor rendahnya keyakinan diri siswa dalam menyelesaikan masalah matematika yang dihadapi siswa. Sikap keyakinan diri siswa dalam menghadapi situasi tertentu disebut dengan self- efficacy (Bandura, 2009).

\section{TINJAUAN TEORI}

Masalah matematika merupakan suatu persoalan yang menggugah siswa merasa tertantang dalam menyelesaiakanya. dalam menyelesaikan suatu masalah matematika dibutukan suatu kompetensi pemecahan masalah siswa. Pemecahan masalah matematika adalah suatu usaha yang dilakukan siswa dalam menggunakan pengetahuan, keterampilan, dan pemahaman strategi yang tepat dalam menyelesaikan suatu masalah (Krulik \& Rudnik, 1995). Namun, ketika siswa tidak mampu menggunakan pengetahuan, keterampilan, dan pemahaman strategi penyelesaian yang tepat maka siswa akan kesulitan dalam pemecahan masalah. Bell (1978) kesulitan siswa dalam memecahkan masalah matematika disebabkan oleh kesulitan siswa dalam membaca permasalahan matematika yang dihadapi. Siswa cenderung bisa membaca langsung materi matematika dari buku, namun tidak mampu memahami apa yang sedang dibacanya. Cara terbaik untuk mengidentifikasi penyebab kesulitan siswa adalah meminta siswa membaca permasalahan matematika dengan keras kemudian meminta siswa menginterprestasikannya perkalimat.

Bandura (2009) self-efficacy merupakan keyakinan yang dimiliki siswa mengenai suatu kemampuan menyusun dan menyelesaikan suatu tindakan yang dibutuhkan dalam menyelesaikan suatu masalah. Selain itu, selfefficacy juga berpengaruh pada bagaimana siswa berpikir, merasa dan memotivasi diri sendiri serta dalam bertindak untuk mengatasi suatu masalah. Self Efficacy ini muncul jika siswa menghadapi masalah-masalah yang 
menantang dan bermakna dengan dukungan yang dibutuhkannya agar dapat meraih sukses. Selain itu, efikasi diri muncul dengan mengamati keberhasilan siswa-siswa yang sedang mengerjakan masalah yang sama. Umpan balik yang diberikan oleh guru secara akurat dan memberikan semangat dapat membantu tumbuhnya self-efficacy (Woolfolk, 2009).

\section{METODE PENELITIAN}

Penelitian ini menggunakan pendekatan kualitatif berbasis studi kasus. Tujuan utama dalam penelitian ini adalah menganalisis kesulitan dan self-efficacy siswa MA dalam pemecahan masalah matematika. Jumlah partisipan dalam penelitian ini adalah 22 siswa kelas 11 IPA di salah satu MA Negeri di Lombok, NTB pada semester genap tahun akademik 2018-2019. Penentuan sampel penelitian dilakukan dengan purposive sampling. Pengumpulan data dilakukan dengan dengan instrumen tes dan non tes. Tes dilakukan dengan diagnotis tes yang terdiri dari 6 soal uraian dan non tes dilakukan wawancara dan kuesioner profil self-efficacy siswa menggunakan skala linkert yang terdiri dari 27 pertanyaan dengan rentang skor 0-5.

\section{HASIL DAN PEMBAHASAN}

Hasil pemberian tes uraian dalam menganalisis kesulitan siswa dalam pemecahan masalah menunjukkan bahwa masih banyak siswa yang memiliki kemampuan yang rendah dalam menyelesaikan soal pemecahan masalah matematika. Dari data tes menunjukkan bahwa $36,36 \%$ siswa yang mengalami kesulitan dalam pengetahuan fakta, 54, 54\% siswa kesulitan dalam pengetahuan konseptual, 59,1\% siswa kesulitan dalam penerapan procedural, dan $68,18 \%$ siswa kesulitan dalam metakognitif. Hal ini berarti masih banyak siswa kesulitan dalam memahami suatu masalah yang mengakibatkan siswa tidak mampu menyelesaikan masalah matematika dengan procedural dan strategi yang tepat dalam menemukan solusi yang diinginkan. Hasil wawancara dengan partisipan menunjukkan bahwa kesulitan yang dialami siswa dalam memecahkan matematika yaitu siswa kesulitan mengingat fakta, kesulitan mengingat konsep, memahami fakta dan konsep, menerapkan konsep, menerapkan prosedur penyelesaian masalah, menganalisis prosedur, mengevaluasi faktual, mengevaluasi konsep, mengevaluasi prosedur, dan mengomunikasikan metakognitif.

Secara umum dapat diperoleh informasi bahwa faktor-faktor yang menyebabkan siswa mengalami kesulitan dalam memecahkan masalah matematika yaitu siswa cenderung tidak mampu membaca soal dengan baik, siswa tidak mampu mengingat konsep atau prinsip yang harus digunakan dalam pemecahan masalah matematika dengan baik, siswa tidak mampu memahami permasalahan yang ada sehingga siswa tidak mampu menggunakan prosedur atau langkah yang digunakan untuk memecahkan masalah matematika, siswa tidak mampu menguasai konsep dan memilih strategi yang tepat dalam memecahkan masalah matematika, serta siswa tidak mampu menganalisis jawaban apakah ada kekeliruan yang dilakukan siswa dalam menjawab soal tersebut. Selain itu, terdapat faktor-faktor lain yang mempengaruhi kesulitan siswa dalam menyelesaikan masalah matematika, misalnya: siswa kurang teliti dalam menyelesaikan masalah yang dihadapi, siswa kurang terbiasa menyelesaikan soal-soal non rutin, siswa merasa waktu yang diberikan kurang cukup, siswa sering merasakan cemas saat mengerjakan soal, siswa mudah menyerah, dan siswa merasa tergesa-gesa dalam mengerjakan soal sehingga tidak fokus dalam berpikir dan menemukan ide pemecahan masalah.

Tabel 1. Distribusi Frekuensi Self-Efficacy siswa MA dalam Pemecahan Masalah Matematika

\begin{tabular}{|l|l|l|l|}
\hline Skor $(\mathrm{X})$ & Kriteria & Frekuensi & $\begin{array}{l}\text { Persentase } \\
(\%)\end{array}$ \\
\hline $105<\mathrm{X} \leq 135$ & $\begin{array}{l}\text { Sangat } \\
\text { Tinggi }\end{array}$ & 4 & 18,18 \\
\hline $75<\mathrm{X} \leq 105$ & Tinggi & 6 & 27,27 \\
\hline $55<\mathrm{X} \leq 75$ & Sedang & 12 & 54,54 \\
\hline $35<\mathrm{X} \leq 55$ & Rendah & 0 & 0 \\
\hline $0<\mathrm{X} \leq 35$ & $\begin{array}{l}\text { Sedang } \\
\text { Rendah }\end{array}$ & 0 & 0 \\
\hline
\end{tabular}

Dari table 1. di atas menunjukkan bahwa level self-efficacy siswa MA berada pada kategori sedang dalam menyelesaikan masalah matematika. Hal Ini berarti hanya sedikit siswa MA yang berda pada kategori level self-efficacy 
tinggi dan sangat tinggi dalam menyelesaikan masalah matematika. Hal ini dipengaruhi oleh rendahnya kemampuan siswa dalam pengetahuan dan keterampilan siswa baik konsep dan strategi dalam menyelesaikan masalah matematika sehingga mengakibatkan siswa tidak percaya diri dalam menghadapi masalah matematika yang diberikan dalam setiap pembelajaran dan ujian.

\section{KESIMPULAN}

Berdasarkan latar belakang, rumusan masalah, hasil, dan pembahasan dapat diperoleh kesimpulan bahwa siswa kesulitan dalam pengetahuan fakta, konsep, prosedur, dan metakognitif dalam pemecahan masalah matematika dan level self-efficacy siswa MA berada pada kategori sedang dalam menyelesaikan masalah matematika.

\section{REKOMENDASI}

Beberapa rekomendasi bagi siswa, guru, dan peneliti selanjutnya, yaitu (1) Untuk siswa, hasil penelitian dapat dijadikan sebagai bahan refleksi diri dalam pembelajaran matematika agar dapat meningkatkan kompetensi pemecahan masalah matematika dan level selfefficacy diri dalam pembelajaran, (2) Untuk guru, hasil penelitian ini dapat dijadikan masukkan yang positif sebagai pemicu peningkatan kinerja dan kompetensi dalam pembelajaran dalam membantu siswa dalam peningkatan kemampuan pemecahan masalah dan level self-efficacy siswa dalam pembelajaran, dan (3) Untuk peneliti selanjutnya, hasil penelitian ini dapat dijadikan salah satu bahan kajian dalam penelitian selanjutnya baik mengenai topic yang sama dala pembelajaran matematika dengan pendekatan yang berbeda.

\section{DAFTAR PUSTAKA}

Amri, M., \& Abadi, A. (2013). Pengaruh PMR dengan TGT terhadap motivasi, sikap, dan kemampuan pemecahan masalah geometri kelas VII SMP. PYTHAGORAS: Jurnal Pendidikan Matematika, 8(1), 55-68.
Bandura, A. (2009). Self-efficacy in changing societies. Cambridge, UK: Cambridge University Press.

Bell, F. H. (1978). Teaching and learning mathematics (in secondary school). Dubuque, IO: Wm. C. Brown Company Publisher.

Chambers, P. (2008). Teaching mathematics: developing as a reflektive secondary teacher. London, UK: Sage Publication.

Krulik, Stephen dan Rudnick, Jesse A. (1995). The New Sourcebook for Teaching Reasoning and Problem Solving in Elementary School. Boston : Temple University.

NCTM. (2000). Principles and standards for school mathematics. Reston, VA: The National Council of TeacPhers of Mathematics, Inc.

OECD. (2018). PISA 2018 Results: what students know and can do - student performance in mathematics, reading and science (Volume 1, Revised Edition, February 2018). PISA: OECD Publishing.

Woolfolk, A. (2009). Education psychology. Boston, MA: Pearson Educational Inc. 